Eur. J. Clin. Chem. Clin. Biochem.

Vol. 32, 1994, pp. 511-514

(C) 1994 Walter de Gruyter \& Co.

Berlin · New York

\title{
Prognostic Significance of Autoantibodies to Laminin in the Sera of Breast Cancer Patients: A Preliminary Report ${ }^{1}$ )
}

\author{
By M. R. Barbouche ${ }^{1}$, Sylvie Romain ${ }^{2}$, S. Avrameas ${ }^{1}$, Lucien Piana ${ }^{3}$ and P.-M. Martin ${ }^{2}$ \\ 1 Laboratoire d'Immunocytochimie, URA 359 du CNRS, Institut Pasteur, Paris, France \\ 2 Laboratoire de Cancérologie Biologique, Faculté de Médecine Nord, Marseille, France \\ 3 Service de Gynécologie, Hôpital de la Conception, Marseille, France
}

(Received November 29, 1993/April 11, 1994)

Summary: Interactions between cancer cells and laminin play an important role in the metastatic cascade. The aim of this retrospective study was to evaluate the presence and the prognostic significance of autoantibodies to laminin in sera of patients with breast cancer. Our study population consisted of 71 high-risk primary breast cancer patients (median follow-up, 6 years). IgG, IgA and IgM were analysed at the time of surgery and before any treatment was given. Concentrations were measured by enzyme immunoassay with a highly purified antigen. IgG, IgA and IgM anti-laminin median values were, respectively $117 \%, 130 \%$ and $97 \%$ of normal absorbance. Higher concentrations of IgM to laminin were found in pre-menopausal patients as compared with post-menopausal patients $(p<0.001)$. Patients with high concentrations of IgG to laminin had lower disease-free $(p=0.003)$ and overall survival rates $(p=0.003)$. In breast cancer, assay of IgG to laminin could thus provide a cheap and easy prognostic index available for all patients.

\section{Introduction}

Autoantibodies of various specificities have been identified in the sera of patients suffering from neoplasic diseases $(1-5)$. In breast cancer, until now, only anti-nuclear and anti-smooth muscle autoantibodies have been correlated with the clinical course of the disease (6).

Cancer invasiveness is determined by basement membrane fragmentation. Interactions between cancer cells and laminin, the main glycoprotein of basement mem= branes, play an important role in the metastatic cascade (7). In addition, laminin-derived peptides stimulate angiogenesis and tumour growth (8).

The aim of this retrospective study was to evaluate the presence and the prognostic significance of autoantibod-

\footnotetext{
1 This work was suppoted by grant No. 6257 from Association pour la Recherche sur le Cancer.
}

ies to laminin in sera of 71 high-risk primary breast cancer patients. The association of IgG, IgA and IgM antilaminin with classical prognostic factors, disease-free and overall survival was studied to determine their possible clinical usefulness.

\section{Materials and Methods}

Patients

Our study population consisted of 71 high-risk primary breast cancer patients (mean age $=51$ years; range $=33-67$ years) who were treated by the same clinical team between 1984 and 1988 (tab. 1). The median follow-up was 6 years (maximum follow-up, 8 years). All patients had undergone partial mastectomy with axillary lymph node clearance and post-operative irradiation as part of the locoregional treatment. Patients received adjuvant chemotherapy $(n=34)$ or hormone therapy $(n=37)$. At the time of analysis, 27 patients had distant metastases and 20 had died of cancer.

Macroscopic tumour size was defined as the largest tumour diameter measured by the pathologist. Axillary node involvement was determined by pathological examination of at least 10 nodes per 
Tab. 1 Characteristics of patients

\begin{tabular}{|c|c|c|}
\hline \multirow[t]{2}{*}{ Condition } & \multicolumn{2}{|c|}{ Number of probands } \\
\hline & absolute & $\begin{array}{l}\text { relative } \\
(\%)\end{array}$ \\
\hline $\begin{array}{l}\text { Age (yearss) } \\
\quad<50 \\
\quad \geq 50\end{array}$ & $\begin{array}{l}28 \\
43\end{array}$ & $\begin{array}{l}39.4 \\
60.6\end{array}$ \\
\hline $\begin{array}{l}\text { Menopausal status } \\
\text { Pre- } \\
\text { Post- }\end{array}$ & $\begin{array}{l}31 \\
40\end{array}$ & $\begin{array}{l}43.7 \\
56.3\end{array}$ \\
\hline $\begin{array}{l}\text { Size of iumour }(\mathrm{cm}) \\
\quad<2 \\
{[2-5]} \\
\geq 5 \\
\text { unknown }\end{array}$ & $\begin{array}{r}16 \\
44 \\
6 \\
5\end{array}$ & $\begin{array}{r}22.5 \\
62.0 \\
8.5 \\
7.0\end{array}$ \\
\hline $\begin{array}{l}\text { Number of axillary nodes } \\
\quad<3 \\
\quad \geq 3\end{array}$ & $\begin{array}{l}13 \\
58\end{array}$ & $\begin{array}{l}18.3 \\
81.7\end{array}$ \\
\hline $\begin{array}{l}\text { Histological grade (SBR) } \\
\text { I } \\
\text { II } \\
\text { III } \\
\text { unknown }\end{array}$ & $\begin{array}{r}6 \\
25 \\
35 \\
5\end{array}$ & $\begin{array}{r}8.5 \\
35.2 \\
49.3 \\
7.0\end{array}$ \\
\hline $\begin{array}{l}\text { Oestrogen receptors } \\
\quad<10 \mathrm{nmol} / \mathrm{kg} \text { protein } \\
\geq 10 \mathrm{nmol} / \mathrm{kg} \text { protein } \\
\text { unknown }\end{array}$ & $\begin{array}{r}23 \\
46 \\
2\end{array}$ & $\begin{array}{r}32.4 \\
64.8 \\
2.8\end{array}$ \\
\hline $\begin{array}{l}\text { Progesterone receptors } \\
\quad<10 \mathrm{nmol} / \mathrm{kg} \text { protein } \\
\geq 10 \mathrm{nmol} / \mathrm{kg} \text { protein } \\
\text { unknown }\end{array}$ & $\begin{array}{r}33 \\
36 \\
2\end{array}$ & $\begin{array}{r}46.5 \\
50.7 \\
2.8\end{array}$ \\
\hline
\end{tabular}

* SBR: Scarff, Bloom, Richardson classification (9)

patient. The histological grade was determined using the method of Scarff, Bloom and Richardson as decribed in l. c. (9).

\section{Assay of steroid receptors}

Oestrogen and progesterone receptors were assayed using the dextran-coated charcoal method (cut-off, $10 \mathrm{nmol} / \mathrm{kg}$ protein). Quality control was assured by frequent testing with both internal controls and European Organization for Research and Treatment of Cancer (EORTC) standards (10).

\section{Assay of autoantibodies to laminin}

The sera were collected at the time of surgery and prior to therapy and stored at $-20^{\circ} \mathrm{C}$. Concentrations of autoantibodies to laminin were measured by enzyme immunoassay as previously described (11). Laminin antigen was highly purified from mouse EngelbrethHolm-Swarm sarcoma extracts by anion exchange chromatography and gel filtration as previously described (12).

\section{Calculation}

Results of autoantibody assay are expressed as relativè absorbance:

$$
\frac{\text { absorbance of tested serum }}{\text { absorbance of pool of } 80 \text { normal sera }} \cdot 100(\%) \text {. }
$$

\section{Statistics}

Relationships between autoantibody concentrations were analysed using the Spearman rank test; differences in the distribution among patients subgroups were studied using the Mann-Whitney $U$ test. Survival rates, calculated according to the Kaplan-Meier method were compared using the log rank test. The cut-off value for autoantibodies to laminin was established in order to achieve the highest chi-square value $\left(\chi^{2}\right)$ resulting from log rank tests.

\section{Results}

\section{Distribution of autoantibodies to laminin}

$\operatorname{IgG}, \operatorname{IgA}$ and $\operatorname{IgM}$ anti-laminin concentrations (relative absorbance values) were, respectively: means $\pm \mathrm{SD}$ : $133 \pm 79 \%, 159 \pm 93 \%$ and $124 \pm 90 \%$; medians: $117 \%, 130 \%$ and $97 \%$ (fig. 1). The concentrations of IgG and IgA autoantibodies to laminin were highly correlated $(\mathrm{p}<0.001)$. IgM concentrations were more weakly correlated to $\operatorname{IgG}(p=0.002)$ and to $\operatorname{IgA}$ concentrations $(p=0.02)$.

\section{Association between autoantibodies to laminin and tumour characteristics}

Higher concentrations of IgM to laminin were found in pre-menopausal patients, compared with post-menopausal patients (median 138 vs $85 \%$ relative absorbance) $(p<0.001)$. No other significant correlation was found between autoantibodies to laminin and tumour size, axillary node involvement, histological grade or steroid receptors.

\section{Associations between autoantibodies to} laminin and other factors with (disease-free) survival

Menopausal status, tumour grade, oestrogen receptor and progesterone receptor status showed no significant
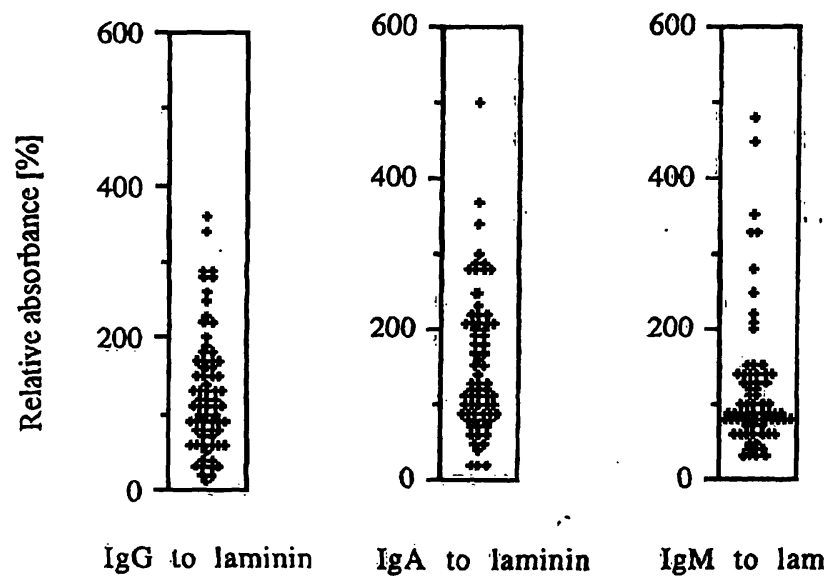

IgG to laminin

IgA to laminin

IgM to laminin

Fig. 1 Distribution of antibodies to laminin in the sera of 71 breast cancer patients. Concentrations are expressed as relative absorbance (comparison with a pool of 80 normal sera), see section "Calculation". 
association with disease-free and overall survival. Larger tumour size was associated with reduced diseasefree $(p=0.0003)$ and overall survival $(p=0.0002)$. The number of axillary lymph nodes involved was positively associated with both a shorter disease-free $(p=0.02)$ and overall survival $(p=0.01)$.

Analysis of a possible correlation between autoantibodies and outcome showed that patients with high concentrations of IgG to laminin had lower survival rates. The cut-off value was established to achieve the best clinical correlation. The highest $\chi^{2}$ was observed at a cut-off of $210 \%$ relative absorbance (disease-free survival, $\chi^{2}=8.96, \mathrm{p}=0.003$; overall survival, $\chi^{2}=8.57$, $\mathrm{p}=0.003$ ) (fig. 2). No significant association could be found between prognosis and the concentrations of $\operatorname{IgA}$ or IgM to laminin.

\section{Discussion}

We demonstrate here a high incidence of antibodies to laminin to the sera of breast cancer patients at the time of diagnosis and before any therapeutic intervention. Dysregulation of the immune system and accelerated lysis of neoplastic tissues have been proposed as stimuli for autoantibody production in patients with malignancies (13).

Laminin has been implicated in cell adhesion and migration. In previous studies, it was suggested that intratumoural laminin distribution (14), laminin receptors (15), serum (16) and urinary (17) laminin fragments may have a prognostic value in breast cancer. We found a statistically significant association between IgG antibodies to laminin and poor prognosis. Although this association needs to be confirmed in prospective clinical trials including more patients, assay of IgG to laminin would provide a cheap and easy test available for all patients.

Several proteases, including principally the cathepsin D (18) and the urokinase plasminogen activator (19), have been associated with an increased risk of developing metastasis in breast cancer. Intratumoural proteases only reflect tumour aggressiveness at the time of surgery,

\section{References}

1. Whitehouse, J. M. A. \& Holborow, E. J. (1971) Smooth muscle antibody in malignant disease. Br. Med. J. 4, 511-513.

2. Burnham, T. K. (1972) Antinuclear antibodies in patients with malignancies. Lancet $i$, 436-437.

3. Zeromski, J. D., Gorny, M. K. \& Jarczewska, K. (1972) Malignancy associated with antinuclear antibodies. Lancet $i i$, 1035-1037.

4. Tannenberg, A. E. G., Müller, H. K., Cauchi, M. N. \& Nairn, R. C. (1973) Incidence of autoantibodies in cancer patients. Clin. Exp. Immunol. 15, 153-156.
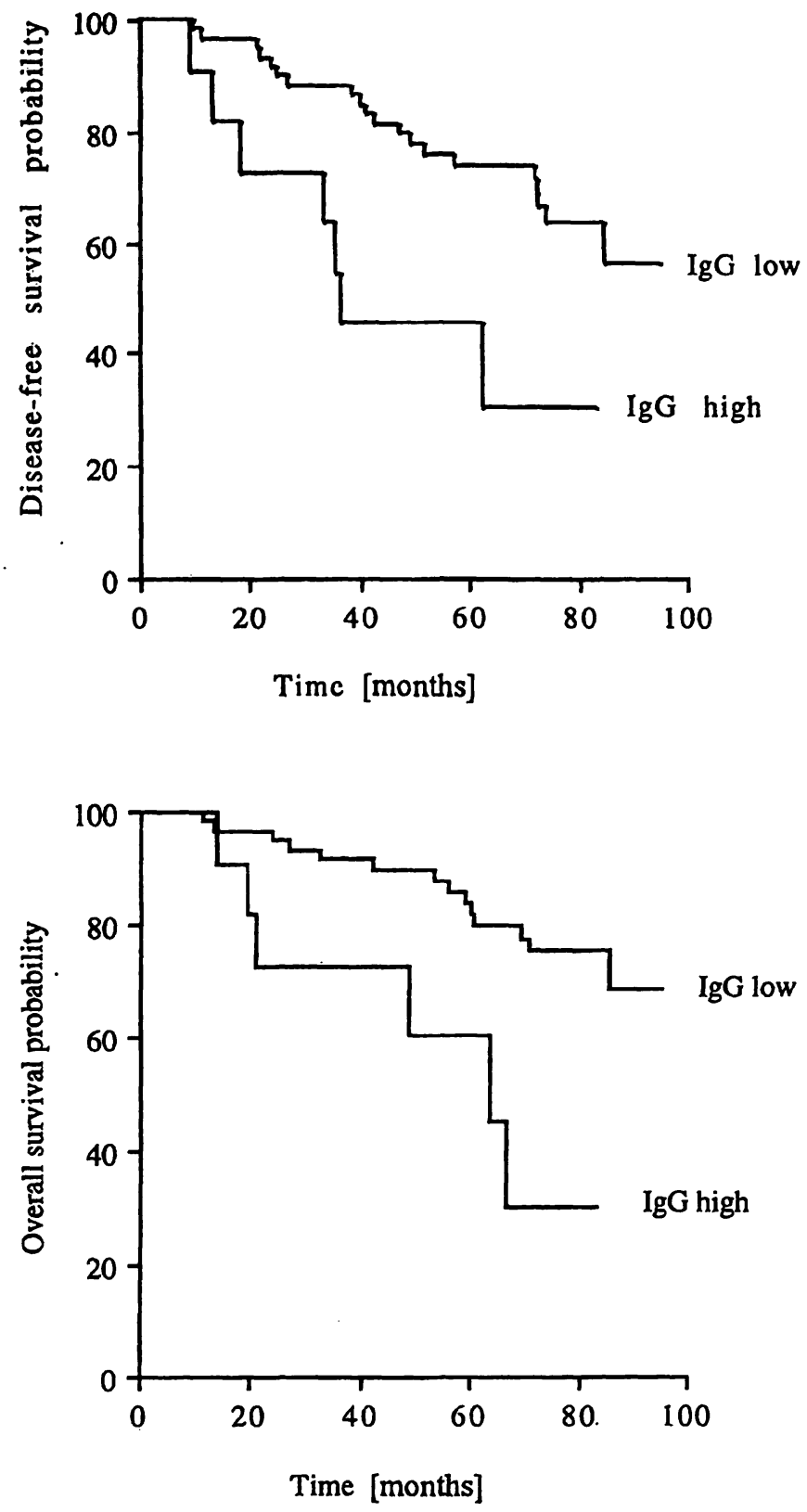

Fig. 2 Disease-free and overall survival of 71 breast cancer patients according to serum concentrations of IgG antibody to laminin. Concentrations are expressed as absorption (comparison with a pool of 80 normal sera), see section "Calculation"; low: $<210 \%$ $(\mathrm{n}=60)$; high: $\geq 210 \%(\mathrm{n}=11)$.

whereas autoantibodies to laminin can be interpreted as the cumulative result of both tumour aggressiveness and the time course of the disease.
5. Faiderbe, S., Chagnaud, J. L., Charrier, M. C., Peyron, M. A., Wafflart, J. \& Geffard, M. (1991) Autoantibodies directed against lipid membrane components in sera of patients with malignant tumors. Cancer Detect. Prev. 15, 199-203.

6. Wasserman, J., Glas, U. \& Blomgren, H. (1975) Autoantibodies in patients with carcinoma of the breast. Correlation with prognosis. Clin. Exp. Immunol. 19, 417-422.

7. Lissitzky, J. C., Cantau, P. \& Martin, P. M. (1992) Heterotrimeric configuration is essential to the adhesive function of laminin. J. Cell Biochem. 48, 141-149. 
8. Kibbet, M. C., Grant, D. S. \& Kleinman, H. K. (1992) Role of the SIKVAV site of laminin in promotion of angiogenesis and tumor growth: An in vivo matrigel model. J. Natl. Cancer Inst. 84, 1633-1638.

9. Bloom, H. J. G. \& Richardson, W. W. (1957) Histological grading and prognosis in breast cancer. $\mathrm{Br}$. J. Cancer 11 , 359-377.

10. Koenders, A. \& Thorpe, S. M. (on behalf of the EORTC Receptor group) (1986) Standardization of steroid receptor assays in human breast cancer. III. Selection of reference material for intra- and inter-laboratory quality control. Eur. J. Cancer Clin. Oncol. 22, 939-944.

11. Louzir, H., Ternynck, T., Gorgi, Y., Ayed, K. \& Avrameas, S. (1988) Enzyme immunoassay analysis of antibody specificity present in the circulating immune complexes of selected pathological sera. J. Immunol. Methods 114, 145-153.

12. Timpl, R., Rohde, H., Robey, P. G., Rennard, S. I., Foidart, J. M. \& Martin, G. R. (1979) Laminin - A glycoprotein from basement membranes. J. Biol. Chem. 254, 9933-9937.

13. Swissa, M., Amital-Teplizki, H., Haim, N., Cohen, Y. \& Shoenfeld, Y. (1990) Autoantibodies in neoplasia. An unresolved enigma. Cancer 65, 2554-2558.

14. Charpin, C., Lisstzky, J. C., Jacquemier, J., Lavaut, M. N., Kopp, F., Pourreau-Schneider, N., Martin, P. M. \& Toga, M. (1986) Immunohistochemical detection of laminin in $98 \mathrm{hu}-$ man breast carcinoma. Human Pathol. 17, 355-365.

15. Daidone, M. G., Silvestrini, R., D'Errico, A., Di Fronzo, G., Benini, E., Mancini, A. M., Garbisa, S., Liotta, L. A. \& Gri- gioni, W. F. (1991) Laminin receptors, collagenase IV and prognosis in node-negative breast cancers. Int. J. Cancer 48 , 529-532.

16. Rochlitz, C., Hasslacher, C., Brocks, D. G. \& Herrmann, R. (1987) Serum concentration of laminin, and course of the disease in patients with various malignancies. J. Clin. Oncol. 5, 1424-1429.

17. Katayama, M., Kamihagi, K., Hirai, S., Kurome, K., Murakami, F., Hino, F. \& Kato, I. (1992) Urinary laminin fragments as a tumour marker potentially reflecting basement membrane destruction. Br. J. Cancer 65, 509 $=514$.

18. Thorpe, S., Rochefort, H., Garcia, M., Freiss, G., Christenisen, Ib J., Khalaf, S., Paolucci, F., Pau, B., Bruun Rasmussen, B. \& Rose, C. (1989) Association between high concentrations of MW 52,000 cathepsin D and poor prognosis in primary breast cancer. Cancer Res. 49, 6008-601.4.

19. Foekens, J. A., Schmitt, M., van Putten, W. L. J., Petters, H. A., Bontenbal, M., Jänicke, F. \& Klijn, J. G. M. (1992) Prognostic value of urokinase-type plasminogen activator in 671 primary breast cancer patienț. Cancer Res. 52, 6101-6105.

S. Romain
Laboratoire de Cancérologie Biologique
Faculté de Médecine Secteur Nord
Boulevard Pierre Dramard
F-13916 Marseille Cedex 20
France

